\title{
Stigmasterol, rengyolone, 2-phenylethyl $\beta$-D-glucopyranoside and n-tetradecyl- $\beta$-D-glucopyranoside from the flowers of Nyctanthes arbor-tristis Linn
}

\author{
M. M. Haque ${ }^{1,2}$, N. Sultana1, S. M. T. Abedin ${ }^{2}$ and S. E. Kabir ${ }^{2 *}$ \\ ${ }^{I}$ Bangladesh Council of Scientific and Industrial Research (BCSIR), Dhaka, Bangladesh \\ ${ }^{2}$ Department of Chemistry, Jahangirnagar University, Savar, Dhaka-1342, Bangladesh
}

Received: 14 March 2018

Revised: 20 January 2019

Accepted: 06 May 2019

DOI: 10.3329/bjsir.v54i3.42680

\begin{abstract}
A phytochemical investigation was conducted on the flowers of Nyctanthesarbor-tristis Linn. For isolation of compounds, the dried flower's powder was successively extracted with n-hexane, dichloromethane, ethyl acetate and methanol. The extracts were fractionated using different chromatographic techniques and four compounds were isolated. Stigmasterol (1) from n-hexane, rengyolone (2) from dichloromethane and two other compounds namely, 2-phenylethyl $\beta$-D-glucopyranoside (3) and $n$-tetradecyl- $\beta$-D-glucopyranoside (4) from ethyl acetate extract, were isolated. These compounds (1-4) were characterized on the basis of IR, ${ }^{1} \mathrm{H}$ NMR, ${ }^{13} \mathrm{C}$ NMR, DEPT-135 NMR. Compounds 1 and 3 were isolated for the first time from this plant while compound 4 has been isolated and completely characterized from this plant as well as from the natural sources.
\end{abstract}

Keywords: Phytochemical investigation; Nyctanthes arbor-tristis Linn; Stigmasterol; Rengyo- lone; 2-Phenylethyl $\beta$-D-glucopyranoside; $n$-Tetradecyl- $\beta$-D-glucopyranoside

\section{Introduction}

Nyctanthes arbor-tristis Linn (Bengali name: Sheuliphul, Shefaliphul) is an important medicinal plant grown throughout the country (Ghani, 2003). This plant normally grows in tropical and sub tropical region (Rani et al., 2012). It is well known in Bangladesh and neighboring countries. It belongs to genus Nyctanthes and the family Oleaceae (Rathod et al., 2010). It was previously reported that the whole Nyctanthes arbor-tristis Linn plant is used for treatment of cancer (Kirtikar and Basu, 2002) while the leaf juice is used to expel roundworms and threadworms in children (Chauhan, 1999) in the treatment of loss of appetite, piles, liver disorders, biliary disorders, chronic fever, malarial fever, obstinate sciatica, rheumatism as well as a diaphoretic agent (Banerjee et al., 2007). The stem bark is used for the treatment of malaria and rheumatic joint pain (Kirtikar and Basu, 2002). The bark is also used to treat bronchitis and snakebite (Rani et al., 2012; Aggarwal et al., 2011; Chatterjee et al., 2007). The plant seed powder is used for scalp scurvy, alopecia and as an anthelmintic agent (Chatterjee et al., 2007; Nair et al., 2005). The seed powder is also used in piles and skin diseases (Kirtikar and Basu, 2002). Among other medicinal uses, the root of the plant is used for the treatment of fever, sciatica and anorexia (Rani et al., 2012). The flowers are used as stomachic, carminative, astringent to bowels, antibilious expectorant, and in the treatment of piles and various skin diseases (Rani et al., 2012). The flower juice is used as a tonic for preventing graying of hairs and hair fall (Girach et al., 1994). The previous phytochemical investigations of this plant resulted in the isolation of nyctantic acid, friedelin, $\beta$-sitosterol, oleanolic acid (Rout et al., 2007), arbortristoside-A, $\beta$-amyrin, nyctoside-A, and 6- $\beta$-hydroxyloganin (Rathore et al., 2007).

In this study, n-hexane, dichloromethane and ethyl acetate extracts of Nyctanthes arbor-tristis Linn flowers were subjected to extensive chromatographic separation to afford a steroid stigmasterol (1), benzofuranonerengyolone (2), and two $\beta$ - D- glucopyranosides 2- phenylethyl $\beta$-Dglucopyranoside (3) and n-tetradecyl- $\beta$-D- glucopyranoside (4) (Fig. 1). These compounds (1-4) were characterized on

*Corresponding author e-mail: skabir_ju@yahoo.com 

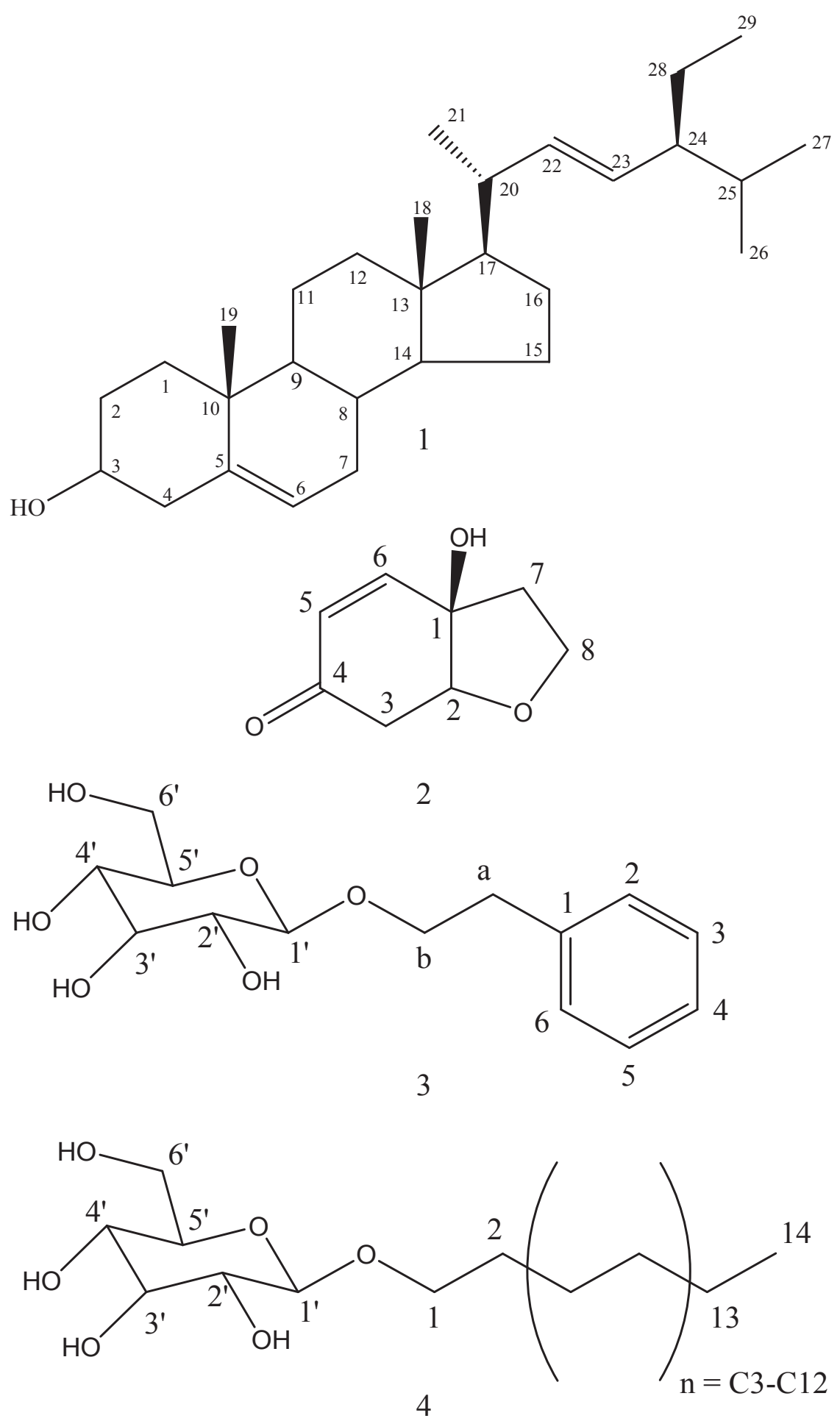

Fig. 1. Structures of compounds 1-4, isolated from the flowers of Nyctanthes arbor-tristis Linn 
the basis of spectroscopic data (IR, ${ }^{1} \mathrm{H}$ NMR, ${ }^{13} \mathrm{C}$ NMR and DEPT-135 NMR) and elemental analysis.

\section{Materials and methods}

\section{General experimental procedures}

Thin layer chromatography (TLC) and preparative thin layer chromatography (PTLC) were performed using pre-coated aluminum sheets and glass plates with silica gel $60 \mathrm{~F}_{254}$ (Merck, Darmstadt, Germany), whereas the columns were wet packed with silica gel $(0.063-0.20 \mathrm{~mm}$, silica gel 60 , AppliChem, Darmstadt, Germany) and vacuum liquid chromatography (VLC) column was packed with TLC grade silica gel $(60 \mathrm{H}, 0.045 \mathrm{~mm}$, Merck, Darmstadt, Germany). NMR spectra were recorded on a Bruker ASCEND ${ }^{\mathrm{TM}} 400$ $\mathrm{MHz}\left({ }^{1} \mathrm{H}\right)$ and $100 \mathrm{MHz}\left({ }^{13} \mathrm{C}\right.$ and DEPT-135) spectrometer. IR spectra were recorded on an IR Affinity-1S SHIMADZU FT-IR spectrophotometer. Melting points were determined on an electro-thermal melting point apparatus (Stuart Scientific SMP3, UK) and are uncorrected. All of the solvents and chemicals used for this research were analytical reagent grade, procured from E. Merck (Germany), BDH (England), AppliChem (Germany) and Sigma Aldrich (Germany).

\section{Plant materials}

The flowers of Nyctanthes arbor-tristis Linn were collected from BCSIR campus, Dhaka, Bangladesh, in October 2013. The plant (specimen \# DACB 38734) was identified from Bangladesh National Herbarium (BNH), Dhaka by their Taxonomist. The collected flowers were air dried at $25-30^{\circ} \mathrm{C}$ in the absence of sunlight. The dried flowers were powdered by a grinder. Then they were weighed and stored in an air tight container in dark until use.

\section{Extraction and isolation}

The dried powdered flower (265.12 g) was extracted successively with n-hexane, dichloromethane, ethyl acetate and methanol at room temperature. Extractions were carried out three times with each solvent and the solvent was evaporated using a vacuum rotary evaporator (BUCHI, Switzerland) at low temperature (below $40{ }^{\circ} \mathrm{C}$ ) under reduced pressure.

Chromatographic separation of n-hexane extract: isolation of compound 1

$4.89 \mathrm{~g}$ of the crude $\mathrm{n}$-hexane extract was purified by repeated column chromatography, eluting first with $100 \%$ n-hexane and then with n-hexane and dichloromethane mixtures of different ratios and finally with $100 \%$ methanol to give 27 fractions. The fractions were combined by their behavior on TLC. Fractions 11-14, MMH-1 (yield $1.575 \mathrm{~g}$ ) was further chromatographed over a AppliChem silica gel column (0.063-0.20 mm). The column was first eluted with $\mathrm{CH}_{2} \mathrm{Cl}_{2}$ : n-hexane, $7: 3, v / v$ and then with increasing polarity of solvent, and then with $100 \%$ dichloromethane and finally with $50 \%$ methanol in $\mathrm{CH}_{2} \mathrm{Cl}_{2}$. Eluates were collected in a series of 33 fractions and were combined based on TLC results. Fractions $14-18$ were identified as MMH-2 (0.2371 g) which was further separated by column chromatography eluting first with $100 \%$ n-hexane and then solvent mixtures with increasing polarity and finally with $5 \%$ ethyl acetate in $\mathrm{CH}_{2} \mathrm{Cl}_{2}$. Eluents were collected in a series of 17 fractions. Fractions 5-11 yielded white needle shaped crystals, identified as MMH-3 (compound 1, $0.048 \mathrm{~g}$ ).

Analytical and spectral data for 1: White needle shaped crystals; Mp. 167-169 ${ }^{\circ} \mathrm{C}$ (Lit. 169-171 ${ }^{\circ} \mathrm{C}$ ) (Koay et al., 2013). IR ( $\left.\mathrm{cm}^{-1}\right): 3238,2934,2864,1651,1454,1445,1051$, 970. ${ }^{1} \mathrm{H}$ NMR $\left(\mathrm{CDCl}_{3}\right): \delta 0.68(\mathrm{~s}, 3 \mathrm{H}), 0.80(\mathrm{~d}, 3 \mathrm{H}), 0.81(\mathrm{t}$, $3 \mathrm{H}), 0.83(\mathrm{~d}, 3 \mathrm{H}), 0.99(\mathrm{~s}, 3 \mathrm{H}), 1.02(\mathrm{~d}, 3 \mathrm{H}), 3.51(\mathrm{~m}, 1 \mathrm{H})$, $5.01(\mathrm{dd}, J=15.2,8.8 \mathrm{~Hz}, 1 \mathrm{H}), 5.14(\mathrm{dd}, J=15.2,8.4 \mathrm{~Hz}$, $1 \mathrm{H}), 5.34(\mathrm{~m}, 1 \mathrm{H}) \cdot{ }^{13} \mathrm{C}$ NMR $\left(\mathrm{CDCl}_{3}\right): \delta 37.3,31.6,71.8$, $42.2,140.8,121.7,31.9,51.2,36.5,21.1,39.7,42.2,56.9$, $24.4,28.9,56.0,12.0,19.4,40.5,21.2,138.3,129.3,51.2$, $31.6,21.2,19.0,25.4,12.3$.

Chromatographic separation of dichloromethane extract: isolation of compound 2

$7.74 \mathrm{~g}$ of the dichloromethane extract was purified by repeated column chromatography, eluting first with $100 \%$ n-hexane and then with increasing polarity with dichloromethane of different ratios and finally with $100 \%$ methanol. Fractions 18 and 19 were combined (MMH-4, 4.97 g). This fraction was further subjected to column chromatography. The column was first eluted with $50 \%$ $\mathrm{CH}_{2} \mathrm{Cl}_{2}$ in n-hexane and then with increasing polarity with $\mathrm{CH}_{2} \mathrm{Cl}_{2}$, finally with $100 \% \mathrm{CH}_{2} \mathrm{Cl}_{2}$ and then with $20 \%$ methanol $(\mathrm{MeOH})$ in $\mathrm{CH}_{2} \mathrm{Cl}_{2}$. Eluates were collected in 27 fractions. Fractions 22-24 were combined and identified as fraction MMH-5 (1.6g). This fraction was further subjected to column chromatography. The column was first eluted with $100 \% \mathrm{CH}_{2} \mathrm{Cl}_{2}$ and finally with $20 \%$ methanol $(\mathrm{MeOH})$ in dichloromethane. Eluents were collected in a series of 42 fractions. The fractions 26-38 were combined and identified as fraction MMH-6 $(0.4648 \mathrm{~g})$. This fraction was subjected to PTL on pre-coated glass plate sheets with appropriate ratio of selected solvent system $\left(\mathrm{CH}_{2} \mathrm{Cl}_{2}: \mathrm{MeOH} 95: 5 \mathrm{v} / \mathrm{v}\right)$. The individual bands on the plates were scraped with the help of a spatula and were extracted several times with $20 \% \mathrm{MeOH}$ in $\mathrm{CH}_{2} \mathrm{Cl}_{2}$. Excess solvent was evaporated by using a rotary 
evaporator. Compound $2\left(0.0969 \mathrm{~g}\right.$, soluble in $\left.\mathrm{CH}_{2} \mathrm{Cl}_{2}\right)$ was finally obtained as colorless oil.

Analytical and spectral data for 2: Colorless oil; boiling point 330-333 ${ }^{\circ} \mathrm{C}$ (Lit. $332.9^{\circ} \mathrm{C}$ ) (Siddiqui et al., 2007; Endo and Hikino, 1984). IR ( $\left.\mathrm{cm}^{-1}\right)$ : 3391, 1667, 1447, 1128, 1061 and 1015. ${ }^{1} \mathrm{H} \mathrm{NMR}\left(\mathrm{CDCl}_{3}\right): \delta 6.71(\mathrm{dd}, J=10.4,1.5 \mathrm{~Hz}, 1 \mathrm{H})$, $5.92(\mathrm{~d}, \mathrm{~J}=10.4 \mathrm{~Hz}, 1 \mathrm{H}), 4.15(\mathrm{ddd}, J=4.4 \mathrm{~Hz}, 1 \mathrm{H}), 4.0$ (ddd, $J=7.2,7.6,6.0 \mathrm{~Hz}, 1 \mathrm{H}), 3.87$ (ddd, $\mathrm{J}=7.6,7.6,8.0 \mathrm{~Hz}$, $1 \mathrm{H}), 2.73(\mathrm{dd}, J=4.0,16.8 \mathrm{~Hz}, 1 \mathrm{H}), 2.54(\mathrm{dd}, J=5.2,17.2$ $\mathrm{Hz}, 1 \mathrm{H}), 2.28$ (ddd, $J=6.4,7.2,13.6 \mathrm{~Hz}, 1 \mathrm{H}), 2.16$ (ddd, $J=$ 6.4, 7.2, $13.6 \mathrm{~Hz}, 1 \mathrm{H}) .{ }^{13} \mathrm{C}-\mathrm{NMR}\left(\mathrm{CDCl}_{3}\right): \delta 75.1(\mathrm{C}-1), 81.2$ (C-2), 39.9 (C-3), 197.5 (C-4), 128.2 (C-5), 148.7 (C-6), 39.3 (C-7), 66.1 (C-8).

Chromatographic separation of ethyl acetate extract: isolation of compound 3

$7.95 \mathrm{~g}$ of the ethyl acetate extract was subjected to vacuum liquid chromatography (VLC). The VLC column was first eluted with $100 \% \mathrm{n}$-hexane and then with increasing polarity with ethyl acetate-n-hexane and ethyl acetate-methanol of different ratios and finally with $100 \% \mathrm{MeOH}$. Eluates were collected in a total of 15 fractions. The fractions of similar $R_{f}$ were combined as MMH-7 (4.3173 g) which was further subjected to column chromatography. The column was first eluted with $100 \% \mathrm{CH}_{2} \mathrm{Cl}_{2}$ and then with $\mathrm{CH}_{2} \mathrm{Cl}_{2}$ and methanol mixtures of different ratios and finally with $40 \%$ methanol in $\mathrm{CH}_{2} \mathrm{Cl}_{2}$. Eluates were collected in 11 fractions. The fraction MMH-8 (1.6450 g) was further subjected to column chromatography. The column was first eluted with $5 \%$ methanol in $\mathrm{CH}_{2} \mathrm{Cl}_{2}$ and then with increasing the polarity of $\mathrm{CH}_{2} \mathrm{Cl}_{2}$ and methanol mixtures of different ratios and finally with $30 \%$ methanol in $\mathrm{CH}_{2} \mathrm{Cl}_{2}$. Eluents were collected in a series of 98 fractions. The fractions $32-41$ combined as MMH-9 and fractions 53-66 were combined as fraction MMH-10 (0.6513 g). The fraction MMH-9 was further subjected to column chromatography. The column was eluted with $2 \%$ methanol in ethyl acetate while a total of 33 fractions were collected. The fractions of similar spots in TLC were combined together and designated MMH-11 which was further identified as compound 3 (0.0868 g).

Analytical and spectral data for 3: Colorless crystalline solid; Mp. 37-39 ${ }^{\circ} \mathrm{C}$ (Lit. $38.5^{\circ} \mathrm{C}$ ) (Joshi and Sawant, 2006). IR $\left(\mathrm{cm}^{-1}\right): 3354,2880,1454,1072,1016 .{ }^{1} \mathrm{H}$ NMR (CD 30 ): $\delta$ $7.21(\mathrm{~m}, 5 \mathrm{H}), 4.28(\mathrm{~d}, J=7.6 \mathrm{~Hz}, 1 \mathrm{H}), 4.07(\mathrm{~m}, 2 \mathrm{H}), 3.82(\mathrm{td}$, $J=12.0,2.4 \mathrm{~Hz}, 1 \mathrm{H}), 3.73(\mathrm{dd}, J=5.6,11.6 \mathrm{~Hz}, 1 \mathrm{H}), 3.69$ $(\mathrm{dd}, J=4.8,12.0 \mathrm{~Hz}, 1 \mathrm{H}), 3.38(\mathrm{~m}, 1 \mathrm{H}), 3.29(\mathrm{~m}, 1 \mathrm{H}), 3.21$ (ddd, $J=2.0,7.2,9.2 \mathrm{~Hz}, 1 \mathrm{H}), 2.91(\mathrm{t}, J=6.8 \mathrm{~Hz}, 2 \mathrm{H})$. ${ }^{13} \mathrm{C}-\mathrm{NMR}\left(\mathrm{CDCl}_{3}\right): \delta 138.3(\mathrm{C}-1), 128.3(\mathrm{C}-2, \mathrm{C}-6), 128.8$ (C-3, C-5), 126.2 (C-4), 102.9 (C-1), 73.5 (C-2), 76.4 (C-3), 70.0 (C-4), 76.0 (C-5), 61.5 (C-6), 36.0 (C-a), 70.6 (C- $\beta$ ).
Chromatographic separation of ethyl acetate extract: isolation of compound 4

The fraction MMH-10 (0.6513 g) was separated by carefully decanting of the mother liquor from the test tube. The fraction was washed with n-hexane and then n-hexane- $\mathrm{CH}_{2} \mathrm{Cl}_{2}$ mixture, finally using one or two drops of methanol. The crystalline fraction was further subjected to column chromatography. The column was first eluted with $100 \%$ ethyl acetate and then with increasing the polarity of solvents of ethyl acetate and methanol mixtures of different ratios and finally 30\% methanol in ethyl acetate. Eluates were collected in a series of 9 fractions. The fractions 5-6 was obtained colorless powder and identified as fraction MMH-12 which shows a single spot on TLC. This fraction was identified as compound $4(0.0012 \mathrm{~g}$, soluble in methanol).

Analytical and spectral data for 4: Colorless powder; Mp. $120-122{ }^{\circ} \mathrm{C}$ (Lit. $119-121^{\circ} \mathrm{C}$ ) (Tickle et al., 1998). IR (KBr, $\left.\mathrm{cm}^{-1}\right): 2918,1081 .{ }^{1} \mathrm{H}$ NMR (CD $\left.\mathrm{OD}\right): \delta 4.26(\mathrm{~d}, J=6.8 \mathrm{~Hz}$, $1 \mathrm{H}), 4.07(\mathrm{~m}, 2 \mathrm{H}), 3.87$ (dd, $J=5.9,11.6 \mathrm{~Hz}, 1 \mathrm{H}), 3.67$ (dd, $J=4.8,12.0 \mathrm{~Hz}, 1 \mathrm{H}), 3.60(\mathrm{dd}, J=6.4,12.4 \mathrm{~Hz}, 1 \mathrm{H}), 3.52$ $(\mathrm{m}, 1 \mathrm{H}), 3.27(\mathrm{~d}, J=6.4 \mathrm{~Hz}, 1 \mathrm{H}), 3.17(\mathrm{t}, J=8.0 \mathrm{~Hz}, 1 \mathrm{H})$, $1.61(\mathrm{~m}, 2 \mathrm{H}), 1.29(\mathrm{~m}, 22 \mathrm{H}), 0.90(\mathrm{t}, J=6.4,13.6 \mathrm{~Hz}, 3 \mathrm{H})$. ${ }^{13} \mathrm{C}-\mathrm{NMR}\left(\mathrm{CDCl}_{3}\right): \delta 69.9(\mathrm{C}-1), 35.7(\mathrm{C}-2), 33.7$ (C-3), 33.1 (C-4), 30.8 (C-5), 30.8 (C-6), 30.7 (C-7), 30.7 (C-8), 30.5 (C-9), 30.5 (C-10), 28.3 (C-11), 26.1 (C-12), 23.7 (C-13), 14.4 (C-14), 104.7 (C-1), 75.0 (C-2), 78.0 (C-3), 71.5 (C-4), 75.5 (C-5), 62.6 (C-6).

\section{Results and discussion}

After fractionation and purification, the structure elucidation of the four compounds isolated from n-hexane (compound 1), dichloromethane (compound 2) and ethyl acetate extracts (compounds 3 and 4) of Nyctanthes arbor-tristis Linn flowers (Fig. 1) was carried out by spectral analysis .

\section{Structural identification for compound 1}

The compound 1 showed positive tests for steroids and alcohols. The IR spectrum exhibits the band of a hydroxyl group at $3238 \mathrm{~cm}^{-1}$ and two sharp absorptions at 2934 and $2864 \mathrm{~cm}^{-1}$ for $\mathrm{C}-\mathrm{H}$ stretching for $\mathrm{sp}^{3}$ hybridized aliphatic carbon. The spectrum also shows absorptions at $1651(\mathrm{C}=\mathrm{C}$ stretching, $\mathrm{sp}^{2}$ ), 1454 (C-H bending $\mathrm{CH}_{2}$ group), and 1445 $\mathrm{cm}^{-1}$ (C-H bending $\mathrm{CH}_{3}$ group). The absorption at $1051 \mathrm{~cm}^{-1}$ is due to $\mathrm{C}-\mathrm{O}$ stretching (primary alcohol) while the absorption at $970 \mathrm{~cm}^{-1}$ is due to $\mathrm{C}-\mathrm{H}$ bending (trans alkene). The ${ }^{1} \mathrm{H}-\mathrm{NMR}$ spectrum exhibits a multiplet at $\delta 3.51$ 
corresponding to one proton, whose position and multiplicity corresponds to the $\mathrm{H}-3$ of the steroid nucleus. A multiplet at $\delta 5.34$, integrating for $1 \mathrm{H}$, is indicative of the typical signal for the olefinic H-6 of the steroid nucleus (steroid skeleton). The down-field resonances at $\delta 5.14(\mathrm{dd}, \mathrm{J}=15.2,8.4 \mathrm{~Hz}$, $1 \mathrm{H})$ and $5.01(\mathrm{dd}, \mathrm{J}=15.2,8.8 \mathrm{~Hz}, 1 \mathrm{H})$ are assigned to olefinic protons (H-22 and $\mathrm{H}-23)$, respectively. The spectrum also contains two singles at $\delta 0.68$ and 0.99 (integrating to $3 \mathrm{H}$ each), assigned to two tertiary methyl groups at C-18 and $\mathrm{C}-19$, respectively. The doublets at $\delta 0.80$ and 0.83 (integrating to $3 \mathrm{H}$ each) are due to two methyl groups at $\mathrm{C}-26$ and $\mathrm{C}-27$ and the doublet at $\delta 1.02(\mathrm{~d}, 3 \mathrm{H})$ is assigned to the methyl group at $\mathrm{C}-21$. On the other hand, a triplet at $\delta 0.81$ (integrating to $3 \mathrm{H}$ ) is due to the primary methyl group at $\mathrm{C}-29$. The ${ }^{13} \mathrm{C}$ NMR spectrum shows the presence of 29 carbon atoms. The signal at $\delta 71.8$ at $\mathrm{C}-3$ carbon atom is characteristics of $\beta$ - hydroxyl group. The resonances at $\delta$ 138.3 and 129.3 correspond to a double bond at C-22 and C-23, respectively. The signals at $\delta 140.8$ and 121.7 for C-5 and C-6 are indicative of another double bond. However, resonances at $\delta 12.0$ and 19.4 represent angular methyl carbon atoms for C-18 and C-19, respectively.

\section{Structural identification for Compound 2}

Functional group test showed positive tests for hydroxyl group. The IR spectrum of this compound exhibits a broad absorption band at $3391 \mathrm{~cm}^{-1}$ (characteristic of O-H stretching) and an absorption at $1667 \mathrm{~cm}^{-1}$ (characteristic of $\mathrm{C}=\mathrm{O}$ stretching). The absorptions at 1061 and $1015 \mathrm{~cm}^{-1}$ are due to C-O stretching of primary alcohol. The absorption at 1447 $\mathrm{cm}^{-1}$ is assigned to aromatic $\mathrm{C}=\mathrm{C}$ stretching, while that at $1128 \mathrm{~cm}^{-1}$ is due to $\mathrm{C}-\mathrm{O}$ stretching of $\mathrm{C}-\mathrm{O}-\mathrm{C}$ group. The ${ }^{1} \mathrm{H}-\mathrm{NMR}$ spectrum reveals the presence of an oxymethylene group $(\delta 4.01$, ddd, $\mathrm{J}=7.2,7.6 \mathrm{~Hz}$ and $\delta 3.87$, ddd, $\mathrm{J}=7.6,8.0$, $7.6 \mathrm{~Hz}, 1 \mathrm{H}$,) adjacent to a methylene group $(\delta 2.28$, ddd, $\mathrm{J}=$ 6.4, 7.2, $13.6 \mathrm{~Hz}, 1 \mathrm{H}$ and $\delta$ 2.16, ddd, $\mathrm{J}=6.4,7.2,13.6 \mathrm{~Hz}$, $1 \mathrm{H})$, an oxymethine group $(\delta 4.15$, ddd, $\mathrm{J}=4.4 \mathrm{~Hz}, 1 \mathrm{H})$ next to another methylene group $(\delta 2.54, \mathrm{dd}, \mathrm{J}=5.2,17.2 \mathrm{~Hz} ; \delta 2.73$, $1 \mathrm{H}, \mathrm{dd}, \mathrm{J}=4,16.8 \mathrm{~Hz}, 1 \mathrm{H})$, and an $\mathrm{a}, \beta$-unsaturated carbonyl group $(\delta 5.92,1 \mathrm{H}, \mathrm{d}, \mathrm{J}=10.4 \mathrm{~Hz} ; 6.71,1 \mathrm{H}, \mathrm{dd}, \mathrm{J}=10.4 \mathrm{~Hz})$. The ${ }^{13} \mathrm{C}-\mathrm{NMR}$ spectrum showed the presence of eight carbon atoms $(\delta 197.5,148.7,128.2,81.2,75.1,66.1,39.9$ and 39.3). In DEPT-135 spectrum, three signals ( $\delta 148.7,128.2$ and 81.2$)$ are as positive only for methine $(\mathrm{CH})$ carbon atoms and three signals $(\delta 66.1,39.9$ and $39.3 \mathrm{ppm})$ are negative signals for methylene $\left(\mathrm{CH}_{2}\right)$ carbon atoms. Two quaternary signals

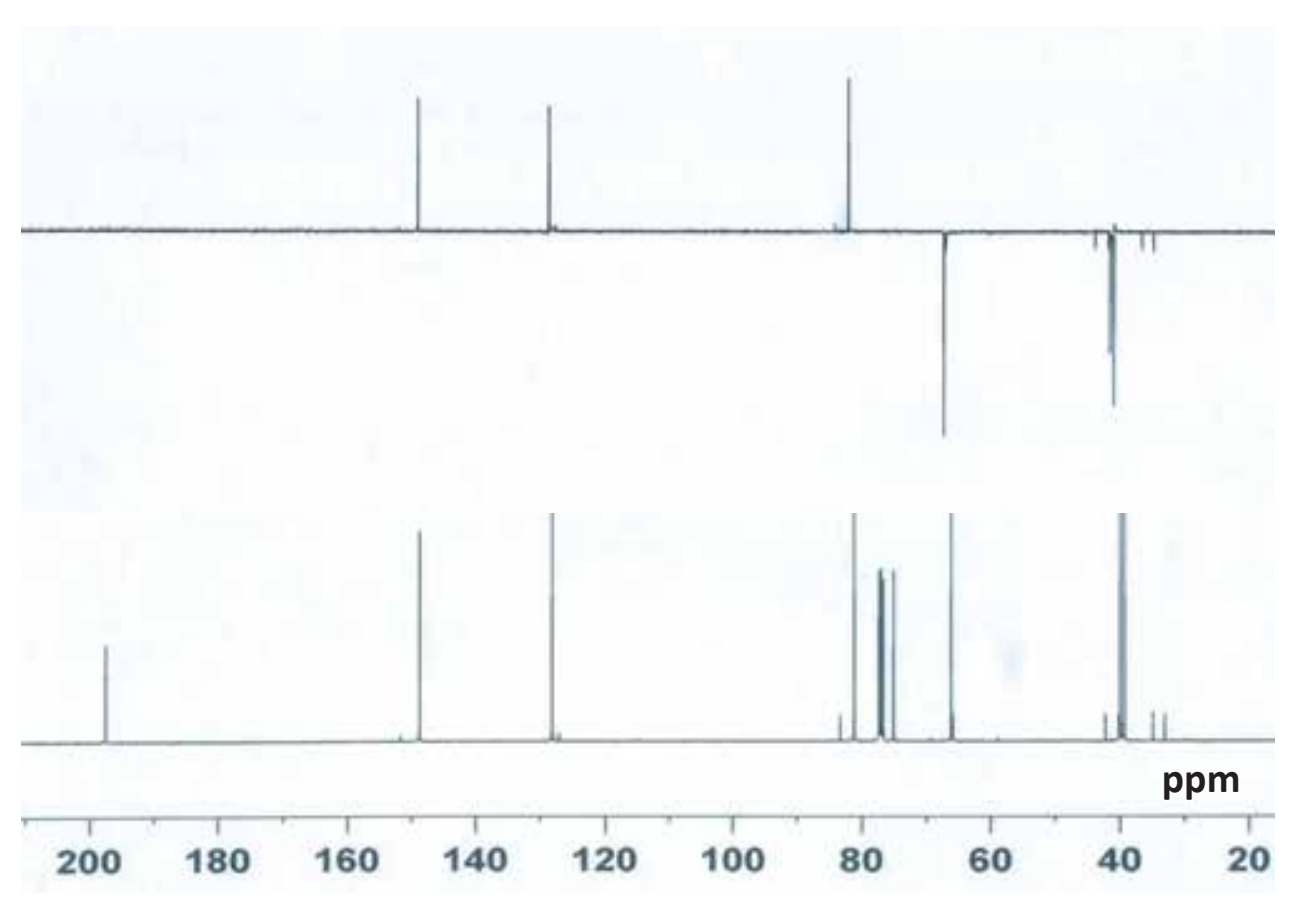

Fig. $2 .{ }^{13} \mathrm{C}\left\{{ }^{1} \mathrm{H}\right\}$ and DEPT-135 NMR spectra of compound 2 
appeared at $\delta 197.5$ and 75.1 of which the former corresponds to a ketonic carbon (C-4). ${ }^{13} \mathrm{C}\left\{{ }^{1} \mathrm{H}\right\}$ and DEPT-135 NMR spectra of compound 2 are provided in Fig. 2.

\section{Structural identification for Compound 3}

The IR spectrum of this compound showed a broad absorption band at $3354 \mathrm{~cm}^{-1}$, characteristic of $\mathrm{O}-\mathrm{H}$ stretching and absorption at $2880 \mathrm{~cm}^{-1}$, characteristic of C-H stretching (aliphatic, $\mathrm{sp}^{3}$ carbon). The absorption band at $1016 \mathrm{~cm}^{-1}$ was due to $\mathrm{C}-\mathrm{O}$ stretching (primary alcohol). Other absorptions were at $1454 \mathrm{~cm}^{-1}(\mathrm{C}=\mathrm{C}$ stretching, aromatic) and $1072 \mathrm{~cm}^{-1}$ (C-O stretching, C-O-C). The ${ }^{1} \mathrm{H}-\mathrm{NMR}$ spectrum of compound 3 showed a multiplet at $\delta 7.21(\mathrm{~m}$, $5 \mathrm{H})$ due to aromatic protons of the benzene ring at $\mathrm{C}-2, \mathrm{C}-3$, $\mathrm{C}-4, \mathrm{C}-5$ and C-6, and a triplet at $\delta 2.91(\mathrm{t}, \mathrm{J}=6.8 \mathrm{~Hz}, 2 \mathrm{H})$ due to the benzylic methylene protons at $\mathrm{C}-\mathrm{a}$. A doublet at $\delta$ $4.28(1 \mathrm{H}, \mathrm{J}=7.6 \mathrm{~Hz})$ indicated a $\beta$-anomeric proton of glycoside moiety. The ${ }^{13} \mathrm{C}-\mathrm{NMR}$ spectrum revealed the presence of 14 carbon atoms. Signals of these carbon atoms and $36.0 \mathrm{ppm})$ are negative signals for methylene $\left(\mathrm{CH}_{2}\right)$ carbon atoms. There is one quaternary signal at $\delta 138.3 \mathrm{ppm}$ (C-1). The ${ }^{13} \mathrm{C}-\mathrm{NMR}$ and DEPT-135 NMR spectra of compound 3 indicated the presence of four oxymethine carbons with chemical shift between $\delta 70.0$ and $76.4 \mathrm{ppm}$, one methylene carbon signal at $\delta 61.5$ and one methine carbon signal at $\delta 102.9$ (C-1) due to an anomeric carbon of a glycoside. This evidence clearly indicates the presence of a glucopyranosyl group. The ${ }^{13} \mathrm{C}-\mathrm{NMR}$ and DEPT-135 NMR spectra of this compound also indicated the presence of another two methylene carbon signals at $\delta 70.6(\mathrm{C}-\beta)$ and 36.0 ppm $(\mathrm{C}-\mathrm{a}) .{ }^{13} \mathrm{C}\left\{{ }^{1} \mathrm{H}\right\}$ and DEPT-135 NMR spectra of compound 3 are provided in Fig. 3.

\section{Structural identification for Compound 4}

The IR spectrum of this compound exhibits absorption bands at $2918 \mathrm{~cm}-1$ (C-H stretching, aliphatic, sp3) and $1081 \mathrm{~cm}^{-1}$ (C-O stretching, C-O-C). The ${ }^{1} \mathrm{H}-\mathrm{NMR}$ spectrum of compound 4 exhibits a triplet at $\delta 0.90(\mathrm{~J}=13.6 \mathrm{~Hz})$ which

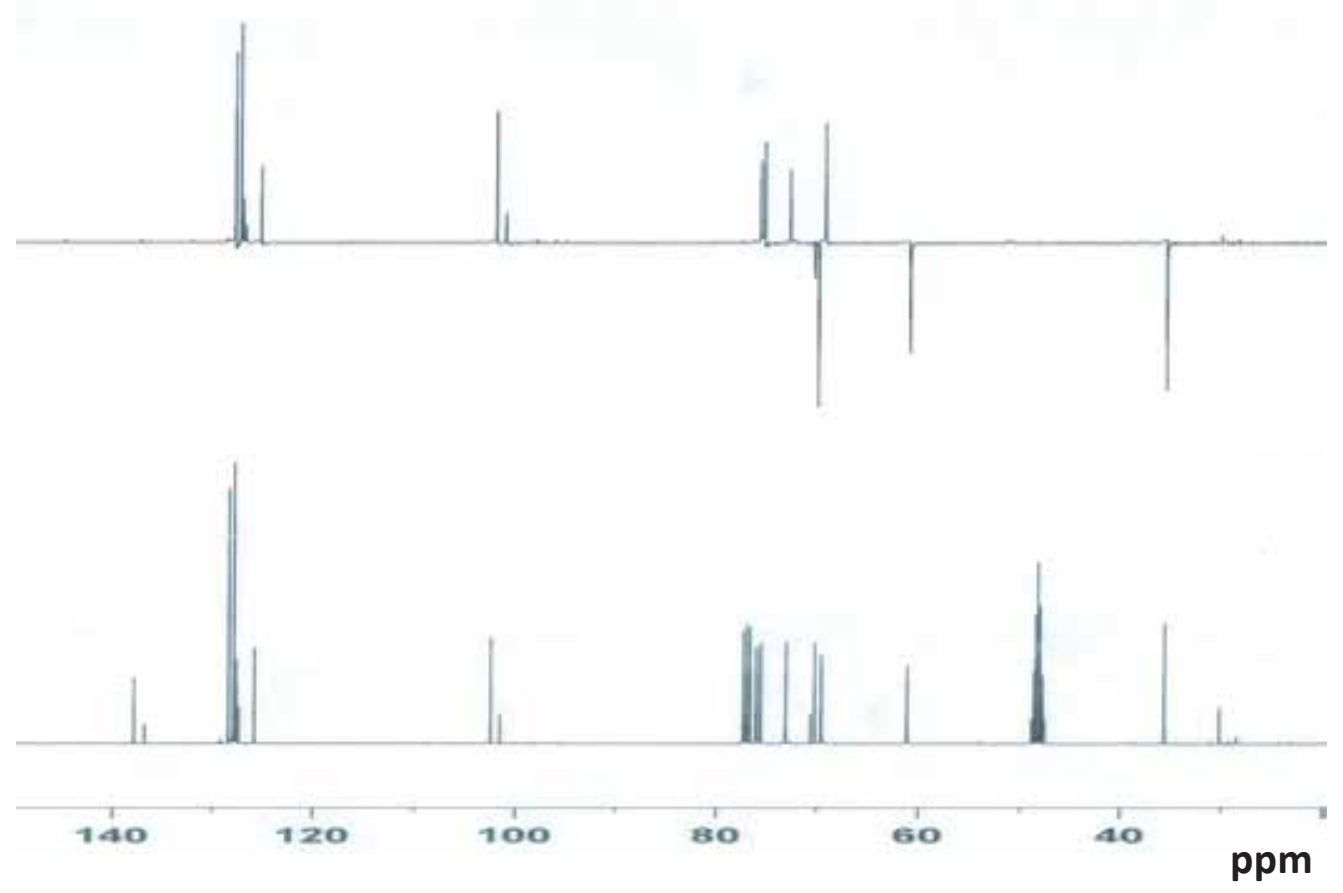

Fig. 3. ${ }^{13} \mathrm{C}\left\{{ }^{1} \mathrm{H}\right\}$ and DEPT-135 NMR spectra of compound 3

were at $\delta 138.3,128.8,128.8,128.3,128.3,126.2,102.9$, $76.4,76.0,73.5,70.6,70.0,61.5$, and 36.0 ppm. In DEPT-135 spectrum, ten signals $(\delta 128.8,128.8,128.3,128.3,126.2$, $102.9,76.4,76.0,73.5$ and $70.0 \mathrm{ppm}$ ) are as positive only for methine $(\mathrm{CH})$ carbon atoms and three signals $(\delta 70.6,61.5$, was due to the primary methyl group at C-14, a methylene proton signal at $\delta 1.29(\mathrm{~m}, \mathrm{C} 3-\mathrm{C} 13,22 \mathrm{H})$ was due to a long chain, suggesting that this compound had an n-alkyl group. A doublet at $\delta 4.26(\mathrm{~d}, \mathrm{~J}=6.8 \mathrm{~Hz}, 1 \mathrm{H})$ indicated a $\beta$-anomeric proton of glycoside moiety. The 13C-NMR spectrum showed 
the presence of 20 carbon atoms in total. The resonance of these carbon atoms are at $\delta 104.7,78.0,75.5,75.0,71.5$, $69.9,62.6,35.7,33.7,33.1,30.8,30.8,30.7,30.7,30.5,30.5$, 28.3, 26.1, 23.7 and $14.4 \mathrm{ppm}$. In DEPT-135 spectrum the positive signal at $\delta 14.4 \mathrm{ppm}$ is assigned to methyl $(\mathrm{CH} 3)$ carbon atoms, and the five positive signals at $\delta 104.7,78.0$, $75.5,75.0$ and $71.5 \mathrm{ppm}$ are assigned to methine $(\mathrm{CH})$ carbon atoms and fourteen signals at $\delta 69.9,62.6,35.7,33.7,33.1$, $30.8,30.8,30.7,30.7,30.5,30.5,28.3,26.1$ and $23.7 \mathrm{ppm}$ were negative signals for methylene $(\mathrm{CH} 2)$ carbon atoms. There are no quaternary signals for this compound. The ${ }^{13} \mathrm{C}$-NMR and DEPT-135 NMR spectra of compound 4 indicated the presence of four oxymethine carbons with chemical shift between $\delta 71.5$ and $78.0 \mathrm{ppm}$, one methylene carbon signal at $\delta 62.6$ and one methine carbon signal at $\delta$ 104.7 (C-1区) due to an anomeric carbon of a glycoside. Evidences clearly indicate that it is a substituted glucopyranosyl molecule.

\section{Conclusions}

In summary, the spectroscopic data of compound 1 is in complete agreement to those reported for stigmasterol (Nayak et al., 2015; Koay et al., 2013; Jamal et al., 2008; Jain and Bari, 2010). The spectroscopic data of compound 2 is in complete agreement to the data reported for rengyolone. (Siddiqui et al., 2007; Endo and Hikino, 1984). For the compound $\mathbf{3}$ on the other hand, the physical and spectral data was in complete agreement to the reported data in literature (Joshi and Sawant, 2006; Kim et al., 2008; Schwab and Schreier, 1988; Umehara et al., 1988). Thus compound 3 has been characterized as 2-phenylethyl $\beta$-D-glucopyranoside. It is also concluded that two compounds ( 1 and 3 ) were isolated for the first time from this plant. The compound 4 has been characterized as n-tetradecyl- $\beta$-D-glucopyranoside (Figure 1) and the physical and spectral data is in complete agreement with the data reported in the literature (Tickle et al., 1998; Joshi and Sawant, 2006). Compound 4 has been isolated and completely characterized from this plant as well as from other natural sources.

\section{References}

Aggarwal BB, Prasad S, Reuter S, Kannappan R, Yadev VR, Park B, Kim JH, Gupta SC, Phromnoi K, Sundaram C, Prasad S, Chaturvedi MM and Sung B (2011), Identification of novel anti-inflammatory agents from ayurvedic medicine for prevention of chronic diseases: "reverse pharmacology" and "bedside to bench" approach, Current Drug Targets 12(11): 1595-1653. DOI:org/10.2174/138945011798109464
Banerjee A, Poddar A, Ghanta S, Chakraborty A and Chattopadhyay S (2007), Nyctanthes arbor-tristis Linn - spectrum of its bioactivity potential, Planta Medica 73(9): 805-805.

Chatterjee SK, Bhattacharjee I and Chandra G (2007), Bactericidal activities of some common herbs in India, Pharmaceutical Biology 45(5): 350-354. DOI:org/10.1080/13880200701212940

Chauhan NS (1999), Medicinal and Aromatic Plants of Himachal Pradesh, Gidwani Publishing Company, New Delhi, p 288.

Endo K and Hikino H (1984), Structures of rengyol, rengyoxide, and rengyolone, new cyclohexylethane derivatives from Forsythia suspense fruits, Can. J. Chem. 62(10): 2011-2014. DOI:org/10.1139/v84-343

Ghani A (2003), Medicinal Plants of Bangladesh with Chemical Constituents and Uses. 2 ${ }^{\text {nd }}$ Ed., Asiatic Society of Bangladesh, Dhaka-1000, Bangladesh, p 320 .

Girach RD, Aminuddin SA, Siddiqui PA and Khan SA (1994), Ethnomedicinal studies on Harsingar (Nyctanthes arbor-tristis L.)-A less known medicinal plant in Unani Medicine, Hamdard Med. 37(2): 60-66.

Jain PS and Bari SB (2010), Isolation of Lupiol, stigmasterol and Campesterol from petroleum ether extract of woody stem of Wrightiatinctoria, Asian J. Plant Sci. 9: $163-167$.

Jamal AK, Yaacob WA and Din LB (2008), A Chemical study on Phyllanthus reticulates, Journal of Physical Sciences 19(2): 45-50.

Joshi VY and Sawant MR (2006), A convenient stereoselective synthesis of $\beta$-D-glucopyranosides, Indian J. Chem. 45B: 461-465.

Kim KH, Lee KH, Choi SU, Kim YH and Lee KR (2008), Terpene and phenolic constituents of Lactucaindica L, Arch Pharm Res. 31(8): 983-988.

Kirtikar KR and Basu BD (2002), Indian Medicinal plants, Sri Satguru Publications, New Delhi), VII: 2110-2113.

Koay YC, Wong KC, Osman H, Eldeen I and Asmawi MZ (2013), Chemical constituents and biological activities of Strobilanthescrispus L, Rec. Nat. Prod. 7(1): 59-64. 
Nair R, Kalariya T and Chanda S (2005), Antibacterial activity of some selected Indian medicinal flora, Turkish Journal of Biology 29: 41-47.

Nayak PS, Kar DM and Nayak SP (2015), Isolation and Characterization of stigmasterol from chloroform fraction of aerial part of Argemone Mexicana L, Int. J. Pharm. Pharm Sci. 7(12): 25-29. DOI: rg/ 10.1016/j.jep.2005.04.019

Rani C, Chawla S, Mangal M, Mangal AK, Kajla S and Dhawan AK (2012), Nyctanthes arbor-tristisLinn. (Night Jasmine): A sacred ornamental plant with immense medicinal potentials, Indian J. Traditional Knowledge 11(3): 427-435.

Rathod N, Raghuveer I, Chitme HR and Chandra R (2010), Free Radical scavenging activity of Nyctanthes arbor-tristis in streptozotocin-induced diabetic rats, Indian J. Pha. Ed. Res. 4: 288-294.

Rathore B, Paul B, Chaudhary BP, Saxena AK, Sahu AP and Gupta YK (2007), Comparative studies of different organs of Nyctanthes arbor-tristisin modulation of cytokines in murine model of arthritis, Biomedical and Environmental Sciences 20: 154-159.
Rout GR, Mahato A and Senapati SK (2007), Invitro clonal propagation of Nyctanthes arbor-tristisLinn.-a medicinal tree, Horticulture Sciences (Prague) 34: 84-89.

Schwab W and Schreier P (1988), Aryl $\beta$-D-glucosidesfrom Caricapapaya, Phytochemistry 27(6): 1813-1816.

Siddiqui BS, Ahmad F, Sattar FA and Begum S (2007), Chemical constituents from the aerial parts of Lippianodiflora Linn, Arch. Pharm. Res. 30(12): 1507-1510.

Tickle D, George A, Jennings K, Camilleri P and Kirby AJ (1998), A study of the structure and chiral selectivity of micelles of two isomeric D-Glucopyranoside based surfactants, J. Chem. Soc., Perkin Trans. 2: 467-474. DOI: $10.1039 / \mathrm{A} 708418 \mathrm{H}$

Umehara K, Hattori I, Miyase T, Ueno A, Hara S and Kageyama C (1988), Studies on the constituents of Leaves of Citrus unshiuMarcov, Chem. Pharm. Bull. 36(12): 5004-5008. 